\title{
PROTHROMBOTIC COAGULATION FACTORS (PTCF) IN SYMPTOMATIC NEONATAL CEREBRAL INFARCTION (SNCI). WHAT IS THEIR ROLE?
}

\author{
A. Garcia-Alix ${ }^{1}$, A. Martin Ancel ${ }^{1}$, V. Cortes ${ }^{1}$, T. Agut ${ }^{1}$, G. Arca ${ }^{2}$, A. Catala ${ }^{3}$, J. Arnaez ${ }^{4}$
}

${ }^{1}$ Pediatrics, Hospital Sant Joan de Deu. Universidad de Barcelona, ${ }^{2}$ Pediatrics, Hospital Clinic-Maternitat. Universidad de Barcelona, Barcelona, ${ }^{3}$ Pediatrics, Hospital Sant Joan de Deu, Universidad de Barcelona, Bacelona, ${ }^{4}$ Pediatrics, Hospital La Paz, Autonoma University, Madrid, Spain

Background: PtCFs have been associated with SNCI, but their relative risks is still unknown.

Objective: To examine the extent to which single and combined PtCF influence the onset of SNCI.

Methods: Prospective multicenter case-control study. Factor V (FV) G1691A mutation; Prothrombin (PT) G20210A variant; MTHFR T677T genotype; Antithrombin III (AT); Protein C; Protein S; Lipoprotein (Lpa); Homocystein and anticardiolipin antibodies were investigated in 29 infant-mother pairs with SNCI and in 28 infant-mother control pairs.

Results: Eight of 29 patients (28\%) had at least 1 PtCF compared with 9/28(33\%) controls. PtCF were found in $17(58 \%)$ mothers of infants with infarction and in 9(36\%) of mothers of healthy infants (OR 2,1,95\%CI $0,7-6,4)$. At least 2 factors were found in 2 neonates; one SNIC patient and one healthy control. Two mothers of a SNIC patient and a control, respectively, had at least 2 factors.

\begin{tabular}{|l|c|c|c|c|c|c|}
\hline & \multicolumn{2}{|c|}{ Neonates } & P & \multicolumn{2}{c|}{ Mothers } & P \\
\hline & $\begin{array}{c}\text { Cerebral } \\
\text { infarction }\end{array}$ & Control & & $\begin{array}{c}\text { Cerebral } \\
\text { infarction }\end{array}$ & Control & \\
\hline FV & $3(10 \%)$ & $1(4 \%)$ & NS & $2(8 \%)$ & $0(0 \%)$ & NS \\
\hline PT & $2(7 \%)$ & $0(0 \%)$ & NS & $2(8 \%)$ & $1(4 \%)$ & NS \\
\hline $\begin{array}{l}\text { MTHFR } \\
\text { homozygosis }\end{array}$ & $1(5 \%)$ & $2(10 \%)$ & NS & $2(20 \%)$ & $1(4 \%)$ & NS \\
\hline AT & 0 & 0 & - & 0 & 0 & - \\
\hline Prot C deficiency & 0 & 0 & - & 0 & 0 & - \\
\hline Prot S deficiency & $1(4 \%)$ & $1(4 \%)$ & NS & 0 & $1(4 \%)$ & NS \\
\hline Lpa>30 & $2(8 \%)$ & $0(0 \%)$ & & $5(29 \%)$ & $6(25 \%)$ & NS \\
\hline Homocystein $>12$ & $0(0 \%)$ & $2(7 \%)$ & NS & $3(18 \%)$ & $1(4 \%)$ & NS \\
\hline Anticardiolipin Abs & 0 & 0 & NS & 3 & 0 & NS \\
\hline
\end{tabular}

Conclusion: Our data indicate that PtCF do not appear to play a major role in SNCI. 